\title{
Payments for ecosystem services: From local to global
}

\author{
Joshua Farley ${ }^{\mathrm{a}, \mathrm{b}, *}$, Robert Costanza ${ }^{\mathrm{b}, 1}$ \\ a Department of Community Development and Applied Economics, University of Vermont, Burlington, VT, 05405, USA \\ ${ }^{\mathrm{b}}$ Gund Institute for Ecological Economics, University of Vermont, Burlington, VT, 05405, USA
}

\section{A R T I C L E I N F O}

\section{Article history:}

Received 7 June 2010

Accepted 11 June 2010

Available online 6 July 2010

\section{Keywords:}

Payments for ecosystem services

Public goods

Open access regimes

Congestibility

Collective institutions

\begin{abstract}
A B S T R A C T
Payment for Ecosystem Services (PES) is becoming increasingly popular as a way to manage ecosystems using economic incentives. The environmental economics approach to PES tries to force ecosystem services into the market model, with an emphasis on efficiency. The ecological economics approach, in contrast, seeks to adapt economic institutions to the physical characteristics of ecosystem services prioritizing ecological sustainability and just distribution and requiring a transdisciplinary approach. This paper summarizes the results of a participatory "atelier" workshop held in Costa Rica. We developed a set of principles (the Heredia Declaration) for PES systems and report on evolving initiatives in several countries. We discuss how the distinction between ecosystem goods (which are stock-flow resources) and ecosystem services (which are fund-service resources) and the physical characteristics of the fund-services affect the appropriate institutional form for PES. We conclude that PES systems represent an important way to effectively manage fund-service resources as public goods, and that this represents a significant departure from conventional market institutions.
\end{abstract}

(c) 2010 Elsevier B.V. All rights reserved.

\section{Introduction}

This paper introduces a special section of Ecological Economics on payments for ecosystem services (PES). The bulk of the papers are the results of a scientific atelier (a type of workshop/field-course pioneered by University of Vermont's Gund Institute for Ecological Economics) entitled Payments for Ecosystem Services: From Local to Global, held in Heredia, Costa Rica in March 2007, and authored by students, faculty, and stakeholders. This workshop also resulted in the Heredia Declaration on Payments of Ecosystem Services, discussed below. One paper is from another atelier entitled Greening Awassa: Investing in Human and Natural Capital in Ethiopia. Two additional papers contribute important perspectives not covered in the ateliers.

Attesting to the growing attention being paid to payments for ecosystem services (PES), this is the third special section in Ecological Economics on the topic in the past two years. Coincidentally, there are also at least three distinct perspectives on PES. Two of these perspectives parallel the conflicts between environmental economics and ecological economics. The environmental economics approach, as described by Engel et al. (2008) in the first special issue on PES, prioritizes economic efficiency, and tries to force ecosystem services into the market model. The ecological economics approach, as

\footnotetext{
* Corresponding author. 205 B Morrill Hall, University of Vermont, VT 05405, USA Tel.: +55 7194362688 until July 26; +1 8026562989 after August 4; fax: +1 802656 1423.

${ }^{1}$ After Sept. 2010: Director, Center for Sustainable Processes and Practices, Portland State University, USA.
}

described by Muradian et al. (2010) in the second special issue focuses on the multiple goals of ecological sustainability, just distribution and economic efficiency and favors a variety of payment mechanisms to achieve these goals, both market and non-market. Appropriate institutions and mechanisms are determined by and adapted to the relevant characteristics of the ecosystems and services in question. The third perspective largely rejects PES, and even the notion of ecosystem services, as the improper commodification of nature (Kosoy and Corbera, 2010; McCauley, 2006; Robertson, 2006).

The goal of this paper, therefore, is not only to introduce the Scientific Atelier and the Heredia Declaration on PES and articles in the special issue to which it gave rise, but also to reconcile these contrasting views. We take the position that ecosystem services are essential, non-substitutable and poorly understood, and there are real costs to their provision and protection. Someone must pay those costs. Payments however do not require commodification. Only rarely will market payment mechanisms be appropriate. Our goal is to present a unifying framework that adequately addresses all three perspectives and helps to identify what institutions are appropriate for PES based on the physical characteristics of the services in question.

In Section 2 we briefly describe the Scientific Atelier on Payments for Ecosystem Services that led to most of the papers in this volume, and present the Heredia Declaration on PES. In Section 3, we suggest a more detailed definition of ecosystem services based on their physical characteristics, which we believe is more analytically useful than many popular definitions. Section 4 describes the two different approaches to PES in theory and practice, while Section 5 complements Kemkes et al. (2010-this issue) in explaining how the physical 
characteristics of different services help determine what institutions are suitable for PES. We argue that the environmental economics approach is a specific case of the general ecological economics approach. Section 6 presents a summary and conclusion, and introduces the papers in this special issue as illustrations of our central points.

\section{The Payments for Ecosystem Services Atelier and the Heredia Declaration on Payments for Ecosystem Services}

A scientific atelier is an applied integrated research and teaching tool pioneered by the Gund Institute for Ecological Economics. The main elements of ateliers include: (1) transdisciplinary problembased learning and problem solving; (2) community/client sponsorship; (3) deep stakeholder participation; (4) blurring of the distinctions between stakeholders, faculty and student, research and education; (5) adaptive management and flexible working groups; and (6) appropriate and practical communication of results. The PES Atelier introduced the theory behind Payments for Ecosystem Services and explored case studies of relatively successful applications. Participants then applied theory and practice to seek solutions to real life problems. Examples of practical outcomes from the Atelier include:

- Further development of a proposal for a Brazilian national PES policy submitted to the Ministry of the Environment, where the lead author was employed.

- Further development of a proposal for a PES system in the Valle de Bravo Watershed, Mexico and accompanying documents providing 1) program operating rules; 2) an Inter-ministry agreement; 3) a legislative act for PES; 4) a legislative act for economic impacts on ecosystem services and the environmental responsibility of corporations and 5) a governor agreement PES State Commission, all of which have been presented to policy makers.

- A proposal for an international PES system in the Dominican Republic that will protect the habitat of a threatened bird native to the Northeastern US that has already been presented to US beneficiaries who are considering funding the proposal, as well as to Forest Trends (the Katoomba group), which may adopt it as a project.

- This special issue of Ecological Economics;

- The Heredia Declaration on Ecosystem Services, a consensus statement signed by international and local experts outlining the mechanisms for successfully implementing PES at the global, regional and local level, presented here in full:

\section{The Heredia Declaration on Payments for Ecosystem Services Whereas:}

- Ecosystem services (the benefits humans derive from ecosystem functioning ${ }^{2}$ ), and the natural capital assets that produce them, represent a significant contribution to sustainable human wellbeing - larger than the contribution of marketed goods and services. The dominant economic paradigm does not adequately recognize these contributions and we therefore need to develop a new, more comprehensive paradigm.

- Ecosystem services are being threatened and degraded by human activities.

- Many ecosystem services cannot (or should not) be privately owned, and are therefore ignored by conventional markets.

- Many ecosystem services are such that providing benefits to one person does not reduce the amount of benefits available for others (they are "non-rival"), and therefore they should be provided cooperatively and not competitively.

\footnotetext{
2 See more detailed definition below.
}

- There are and will remain enormous uncertainties about how ecosystem services are provided, the magnitude of their benefits, and how human activities affect their provision. Stakes are high, the potential for irreversible outcomes are high, and a precautionary approach to decision-making should therefore be adopted.

- Adaptive institutions need to be developed to adequately deal with ecosystem services and tradeoffs among services so that their contributions to human well-being can be sustained and enhanced. Systems of payment for ecosystem services (PES) can be one effective element in these institutions.

Based on a thorough review and synthesis of information at a workshop in Heredia, Costa Rica, March 8-16, 2007, we recommend the following principles concerning the use of PES systems:

\subsection{Measurement}

We need to continue to develop better methods to measure, map, model, and value ecosystem services at multiple scales. At the same time, we cannot wait for certainty and precision to act. We must synergistically continue the process of improvement of measurements with evolving institutions that can effectively utilize these measurements (see 2.7 below).

\subsection{Bundling}

Most ecosystem services are produced as joint products (or bundles) from intact ecosystems. The relative rates of production of each service varies from system to system and site to site, and time to time, but we must consider the full range of services and the characteristics of their bundling in order to prevent creating perverse incentives and to maximize the benefits to society.

\subsection{Scale-Matching}

The spatial and temporal scale of the institutions to manage ecosystem services must be matched with the scales of the services themselves. Mutually reinforcing institutions at local, regional and global scales over short, medium and long time scales will be required. Institutions should be designed to ensure the flow of information between scales, to take ownership regimes, cultures, and actors into account, and to fully internalize costs and benefits.

\subsection{Property Rights}

Establishing appropriate property rights regimes is essential for implementing PES systems. However, given the public goods nature of most ecosystem services, we can either use existing private property rights, change property rights, or develop systems that can propertize ecosystems and their services without privatizing them. For example, common property asset trusts are one way to effectively do this.

\subsection{Distribution Issues}

The distribution of costs and benefits from PES systems need to be carefully considered. Systems should be designed to ensure inclusion of the poor, since they are more dependent on common property assets like ecosystem services. In particular, wealthier nations should be prevented from free-riding, and instead pay for the services they receive from the biodiverse and ecologically productive ecosystems in less developed countries (see 2.6 below).

\subsection{Sustainable Funding}

PES systems should link beneficiaries with producers. In order to be sustainable, fees should be collected from beneficiaries in order to 
pay producers to continue to provide the services - either by paying private land owners or through investments in commonly owned natural capital assets.

\subsection{Adaptive Management}

Given that significant levels of uncertainty always exist in ecosystem service measurement, monitoring, valuation, and management, we should continuously gather and integrate appropriate information with the goal of learning and adaptive improvement. To do this we should evaluate the impacts of existing PES systems and design new systems as experiments from which we can more effectively quantify performance and learn.

\subsection{Education and Politics}

Two key limiting factors in implementing PES systems are shared knowledge of how the systems work and political will. Both of these can be overcome with targeted educational campaigns, clear dissemination of success and failures directed at both the general public and elected officials.

\subsection{Participation}

All stakeholders (local, regional, and global) should be engaged in the formulation and implementation of PES systems. Full stakeholder awareness and participation contributes to credible, accepted rules that identify and assign the corresponding responsibilities appropriately, and that can be effectively enforced.

\subsection{Policy Coherence}

PES systems will be most effective when they form part of a coherent set of policies to address ecosystem use and management. They are less likely to work when other policy instruments are providing opposing incentives (for example by subsidizing the use of water, energy etc.) or when legislation controlling allocation is inflexible.

\section{Further Defining Ecosystem Services}

We kept the definition of ecosystem services for the Heredia Declaration concise, as required by a brief declaration. Fisher et al. (2008) provide an overview of additional definitions, which range from the MEA's "the benefits people obtain from ecosystems", emphasizing what is provided, to their own "the aspects of ecosystems utilized (actively or passively) to produce human wellbeing" emphasizing the production unit, the ecosystem. One unifying feature of most definitions is that services are defined as processes or functions of value to humans. The emphasis on value is incorrectly interpreted by some critics as commodification, leading them to largely reject the entire concept of ecosystem services (McCauley, 2006). Others recognize the validity of ecosystem services as a metaphor, but argue that thinking of ecosystems as stocks that provide flows of benefits can lead us to seek narrow, market based solutions to ecological problems, blind us to the complexity of ecosystems, promote an inappropriate partial equilibrium framework for analysis, and detract our attention from the need for new institutions for environmental governance (Norgaard, 2010). While these widely used definitions of ecosystem services are useful for concise declarations or for popularizing the notion that ecosystems make major contributions to human well-being, they are excessively broad, easy to misinterpret, and are of limited use in more detailed analysis of payment schemes.

To address this, we propose a more useful definition that first differentiates ecosystem goods as stock-flow resources and ecosystem services as fund-services (in the sense used by Georgescu-Roegen (1971)) provided by nature. The economic subsystem is connected to the ecosystem via two distinct types of flows. The first type of flow is throughput, a physical flow of raw materials and stored energy from nature transformed into economic products then returned to nature as disordered waste. Such resources can be used at the rate we choose, and are physically transformed in the act of production, e.g. forests into houses. They are quantitatively used up. They can also be stockpiled when inflows exceed outflows. Georgescu Roegen referred to such resources as stock-flow in nature. Following Malghan, the stock $x$ of a stock-flow resource, on either the source side or sink side, is given by

$x(\tilde{t})=\int_{0}^{\tilde{t}}\left[f_{\text {in }}(t)-f_{\text {out }}(t)\right] d t$

"where $f_{\text {in }}(t)$ is the flow into the stock at any time $t$ and $f_{\text {out }}(t)$ is the outflow from the stock. $\tilde{t}$ is the current time period and $x(0)$ is the reference stock at time $t=0$." (Malghan, 2006, p. 19). We can think of stock-flow resources from nature as ecosystem goods or ecosystem structure (Daly and Farley, 2010).

In our definition, ecosystem services by contrast are an example of a fund-service, which have fundamentally different physical characteristics. Fund-services are a particular type of flow, or flux, generated by a particular configuration of stock-flow resources. Malghan gives the example of a car, which is a particular configuration of glass, metal, plastic and rubber that provides the service of transportation. A car wreck is a different configuration of exactly the same components that no longer provides the desired service. In the same way, ecosystems are a particular configuration of stock-flow resources that provide a flux of services. Ecosystem services are available at a given rate over time, and cannot be used as fast as we wish. When an ecosystem generates services, it is not physically transformed into the service; it is qualitatively changed, but not quantitatively used up. We cannot stockpile services. As a result, we cannot mathematically model ecosystem services in the same way as ecosystem goods ${ }^{3}$.

What are the advantages of our proposed definition? First of all, most PES schemes actually pay for land uses associated with generating the service, which is to say, they are payments for ecosystem funds. The fund-service definition makes this linkage explicit. Second, it rather nicely encompasses existing definitions-for example, Fisher et al.'s (2008) definition emphasizes the fund side, and the MEA definition the service side. Our definition emphasizes the fact that the two work together. The standard classifications of supporting, regulating, cultural and provisioning services still hold as well; the first three are obvious, while our definition stresses that provisioning service is the capacity of ecosystem structure to reproduce itself, rather than the food, fiber, fuel and water provided (all ecosystem goods). Reproduction in plants and animals occurs at a rate over time, cannot be stockpiled, and leads to qualitative change in the parent generation, not quantitative. Third, the definition focuses on the fund-services' physical characteristics rather than their explicit value to humans. We simply lack adequate understanding of ecosystems to know which functions are of value to humans and which are not, and often only find out after we have destroyed the ecosystem or species that provided them (Farley, 2008; Vatn and Bromley, 1994). Rather than leading to their commodification, defining ecosystem services by their physical characteristics further emphasizes the fact that they do not blend readily with market

\footnotetext{
${ }^{3}$ It's worth noting many conventional economic production functions ignore ecosystem goods all together, focusing only on the fund-services of labor and capital In the somewhat rare occasions when such production functions do include raw material stock-flows, they are assigned the same mathematical units as fund-services, and are treated as substitutes. For example, a pizzeria would be able to hire more cooks or use bigger ovens to produce more pizzas from the same amount of dough, sauce and cheese.
} 
institutions, and other economic institutions may be required to protect and provide them. Fourth, the fact that funds are a particular configuration of stock-flow resources draws attention to the fact that ecosystem services are an emergent property of complex systems. Fifth, the distinction between stock-flow and fund-services stresses the dual nature of natural resources, and helps clarify why market economies systematically favor the conversion of ecosystem structure into stockflow inputs into economic production over its conservation in ecosystem funds in order to provide ecosystem services (Farley, 2010). It also helps illustrate the limits of substitution, as stock-flow and fund-service resources are typically complements ${ }^{4}$.

\section{Two Distinct Approaches to PES}

Most of the literature refers to PES as a market based or marketlike mechanism, and follows Wunder (Wunder, 2005) in defining PES as

\section{“(a) a voluntary transaction where}

(b) a well-defined environmental service (or a land use likely to secure that service)

(c) is being 'bought' by a (minimum one) service buyer

(d) from a (minimum one) service provider

(e) if and only if the service provider secures service provision (conditionality)."

The idea is that ideal PES schemes should integrate ecosystem services into markets, and should be like any other market transaction. PES should "attempt to put into practice the Coase Theorem" (Engel et al., 2008 p. 665). The Coase Theorem states that if private property rights are clearly defined by enforceable contracts, then the generator and recipient of an externality can, through voluntary exchange, potentially reach an agreement that maximizes social welfare. Furthermore, the ultimate level of the externality generating activity will not be affected by the initial assignment of property rights. Aside from the enforcement of property rights, government intervention is not required. This outcome will only occur however in the absence of wealth effects and transaction costs (Coase, 1960). While many proponents of this approach do accept some role for government intervention, most stress defining property rights, creating enforceable contracts, and reducing transactions costs. They also frequently claim that private sector PES schemes are more effective than public sector ones (Wunder et al., 2008).

Associated with this approach is the idea that PES should prioritize efficiency over poverty alleviation (Pagiola et al., 2005; Wunder, 2008). PES is designed to internalize benefits that are currently externalized, thus bringing marginal costs into closer alignment with marginal benefits and increasing economic surplus. Using PES schemes to also alleviate poverty might reduce the economic surplus and future scale of PES. The conventional economic wisdom is that greater poverty alleviation could potentially be achieved by redistributing a larger economic surplus.

However, transaction costs for environmental problems are typically enormous, and wealth effects extremely important (Bromomley, 1991; Muradian et al., 2010). Ironically, Coase himself argued that "[t]he world of zero transaction costs has often been described as a Coasian world. Nothing could be further from the truth. It is the world of modern economic theory, one which I was hoping to persuade the economists to leave." (Coase, 1988, p. 174). We also seek to persuade economists that the Coase Theorem applies to only a very narrow subset of ecosystem services.

It is not surprising then that in real life very few PES schemes achieve the standards proposed by Wunder (Muradian et al., 2010;

\footnotetext{
${ }^{4}$ For example, bigger ovens and bigger cooks cannot compensate for inadequate ingredients in a pizzeria!
}

Porras et al., 2008). We therefore follow Muradian et al. in defining "PES as a transfer of resources between social actors, which aims to create incentives to align individual and/or collective land use decisions with the social interest in the management of natural resources" (Muradian et al., 2010, p. 1205). This approach is far more in line with ecological economics, in which ecological sustainability and just distribution take precedence over market efficiency in furthering social interests (Costanza et al., 1991).

From the ecological economic perspective, Wunder's five rules may be not only unattainable, but also inappropriate. Generating adequate resources or ensuring a just distribution of payments may require non-voluntary approaches such as taxes or mandatory service charges, which is frequently the case in real life PES schemes. Whether payments should be voluntary or coerced through taxation should in fact be determined by the physical characteristics of the resource (Farley et al., 2010-this issue; Kemkes et al., 2010-this issue): services dominated by private good characteristics are amenable to voluntary payments, while services with public good characteristics are not. After all, few economists call for voluntary payments for human-made public good services like fire departments, police departments and national defense. Furthermore, Koellner (2010-this issue) found many private sector firms are reluctant to pay for ecosystem services precisely because they believe that the public sector should do so.

Ecosystems and the services they generate are complex, and it may be appropriate to pay even for poorly defined services. For example, in real life there is considerable uncertainty concerning the water regulation services provided by forests and other land uses, yet dozens of schemes nonetheless pay for these services (Porras et al., 2008). One of the best defined services currently is carbon sequestration, but payments for this single service can have perverse outcomes-monoclonal Eucalyptus plantations may maximize carbon sequestration, but degrade potentially more valuable biodiversity, water provision and nutrient cycling (Lohman, 2006). Transaction costs may also increase as services are more explicitly defined (Rørstad et al., 2007). In the face of ecosystem complexity, we believe that payments for a bundle of loosely defined services are more likely to maximize social benefits.

While at least one "buyer" is required for any PES scheme by definition, schemes like a carbon cap and auction require payments to the institution regulating access to the service rather than to the service provider. ${ }^{5}$

Finally, strict conditionality may not be appropriate. First of all, it can be expensive to enforce, increasing transaction costs substantially. Second, the field of behavioral economics offers evidence that conditional monetary PES (a form of extrinsic motivation) might actually backfire by "crowding out" the intrinsic motivation to do the right thing for society (Kemkes, 2008; Vatn, 2010). Numerous studies show that when people receive a monetary payment for doing something they would have done anyway, their motivation for doing it without payment diminishes, they do it less well if they perceive the payment as inadequate, and they may stop doing it when payment ceases (Ariely et al., 2009; Frey and Jegen, 2001; Gneezy and Rustichini, 2000). This is particularly problematic in light of the fact that PES schemes rarely have permanent sources of funding (Pagiola et al., 2007). Other studies show that monitoring (which is obviously essential for conditionality) may reduce motivation and performance (Falk and Kosfeld, 2006). If payments are seen however as a fair share of the costs of undertaking a desired activity, the recipients may feel an intrinsic obligation to reciprocate (Vatn, 2010). We cannot discard offhand the potential superiority of systems based on reciprocity rather than conditional monetary incentives. In practice, many PES schemes are essentially based on reciprocity already, in that they provide payments up front, often in the form of extension, in the

\footnotetext{
${ }^{5}$ Payments for carbon offsets on the other hand generally do go to the service provider
} 
hopes that recipients will reciprocate by protecting or restoring ecosystem funds (Porras et al., 2008).

If we define markets as systems of voluntary exchange in which prices are determined by the interplay of supply and demand, then most ecosystem services have physical characteristics that make them ill-suited for market provision. Owing to very high transactions costs when dealing with ecosystem services as well as the realities of human behavior, there is no particular reason to believe that a market based approach to PES will be more efficient than non-market alternatives, and even less reason to believe it will be more sustainable or just. As economic institutions can be changed while in most cases the physical characteristics of ecosystem services cannot, we must adapt the former to the latter, and not vice versa.

\section{Economic Institutions and the Characteristics of Ecosystem Services}

Much of the literature on PES explains the market failures affecting the provision of ecosystem services (the public good nature of the services, externalities affecting their provision, incomplete information, and so on) then paradoxically proposes PES as a market-based or market-like mechanism to address the failures (e.g. Engel et al., 2008). The explanation for this paradox is the belief "that the conditions that underlie market failure, namely non-rivalry and non-excludability, are dynamic" (Landell-Mills and Porras, 2002 p. 11). We argue in contrast that rivalry is a purely physical characteristic, and not at all dynamic. Excludability is in some cases a dynamic policy variable, but some ecosystem services are inherently non-excludable as an immutable physical characteristic (Daly and Farley, 2010; Kemkes et al., 2010-this issue). These physical characteristics help determine what economic institutions are appropriate for the sustainable, just and efficient allocation of resources towards the provision of ecosystem services, and for the allocation of ecosystem services among consumers. While PES can play an important role in provision, it can only address the issues of non-rivalry and inherent nonexcludability to the extent that it differs from conventional markets, not to the extent that it mimics them.

\subsection{Excludability and Rationing}

Markets use prices to allocate resources among different products and also to ration those products among different consumers. Market based PES systems must allocate resources towards the provision of ecosystem services in response to a price signal, and ration access to funds or services among beneficiaries according to their willingness to pay; we refer to PES systems that achieve one of these goals as "market-like". Excludability ${ }^{6}$ is a prerequisite for any form of rationing and hence for market-like PES. Non-excludable resources are open access by definition. Property rights are a result of institutions (with enforcement facilitated by adequate monitoring technologies) and hence a dynamic policy variable. Different institutional arrangements can lead to different types of property rights and different types of PES.

On the supply side, market-like PES schemes require that the provider of services have excludable rights to the fund that generates them. Some PES schemes actually reward service providers with land tenure as a form of payment (Porras et al., 2008). In general, transaction costs increase with the number of owners of the fund. However, property rights need not be private: in Mexico, payments are made to ejidos, which share certain property rights to forests (Kosoy et al., 2007), and Brazil's ecological value added tax makes payments to municipal governments (Loureiro, 2002; May et al., 2002; Ring, 2008). Sovereign national property rights are ubiquitous

\footnotetext{
${ }^{6}$ The ability of a person or group to use a good or service and prevent others from using it if so desired.
}

(Farley et al., 2010-this issue). Institutional forms can be adapted to any of these situations.

On the demand side, market-like PES requires excludable rights for the beneficiaries. Excludability in this case ranges from fairly simple to impossible, and is heavily influenced by the spatial distribution of the service in question.

Some ecosystem services are on-site, with the same spatial distribution as the fund that generates them, and existing property rights to the fund generally provide rights to the service as well. Examples include most provisioning services for food, fiber and fuel, for which payment is taken for granted, as well as many recreation services, including hunting ${ }^{7}$ (Ribaudo et al., 2010-this issue). Some ecosystem services, particularly those surrounding water provision and regulation, are directional. Water utility infrastructure, hydroelectric dams and irrigation systems (also fund-services) are examples of technologies and infrastructure that can create exclusive intermediaries between service providers and ultimate beneficiaries. This facilitates the establishment of market-like payment schemes for this service, even though relationships between land use and water provisioning services remain unclear and thus poorly defined (Bruijnzeel, 2004; Porras et al., 2008).

Many regional and global ecosystem fund-services are currently open access, and excludability requires "propertization" - the creation of property rights where none currently exist. Propertization generally requires a collective institution (one representing service beneficiaries) at the scale of the problem. Possible types of collective institutions include the public sector, international protocols, conventions, or treaties, or a commons sector (Barnes, 2006). Property rights can be in the form of property rules, which prohibit others from using the fund-service in the absence of the owner's consent, or in the form of liability rules, in which case others can use the fund-service, but must afterwards compensate the owner ${ }^{8}$ (Bromley, 1978). Property rights can be common or private, assigned to the institution that creates them, assigned to other institutions, distributed equally among all beneficiaries, or distributed to select groups of beneficiaries. Service users can then be charged for access.

Existing institutional arrangements have already propertized a number of formerly open access services, such as the waste absorption capacity for various pollutants. Well known examples under the property rule include the US cap and trade schemes in sulfur dioxide (Burtraw and Mansur, 1999) and water pollutants (Ribaudo et al., 2010-this issue), and the European Union Emission Trading System (Ellerman and Joskow, 2008). Some previously open access funds have also been propertized. For example, the global agreement on Exclusive Economic Zones (EEZ) created national property rights to previously open access coastal waters (United Nations, 1982), which allowed national governments in turn to propertize certain coastal fish populations (Bromley, 2005)-limiting access to the fund of fish populations protects the service of reproductive capacity.

The implicit first step in each of these cap and trade schemes is for the collective institution to declare property rights for itself so that it can then determine the supply of the fund-service available for economic activities, ideally based on the criterion of ecologically sustainable scale. The next step is to determine distribution-who has the rights to the resource, and for how long? Distribution is ideally based on the criterion of justice, though economists focused on efficiency who misinterpret Coase's work frequently overlook the importance of this step (Bromley, 1978). The final step, and the only one involving markets, is to create freely tradable permits. In most cases, permits have been distributed to firms free of charge in proportion to current levels of exploitation, in which case payments

\footnotetext{
7 Property rights to land may not limit recreational access, as is the case in Sweden.

${ }^{8}$ Note that liability rules do not strictly fit the definition of excludability provided above, and would not work on the supply side, as service suppliers could not ensure supply.
} 
for the fund-services occur only when firms wish to consume more than their initial allotment. Another option is for the propertizing institution to retain property rights, then auction them off and decide how to distribute or spend the revenue, which reverses the second and third step. Emission or extraction fees or taxes are an example of a liability rule.

Note that under a property rule, the owner determines the marketable supply of the service, and prices adjust, while under a liability rule, supply adjusts to prices.

While cap and trade systems ration existing supply, offset credits can reward firms for investing in new supplies, allowing supply to adjust to prices. For example, firms can earn tradable permits by investing in land use changes that sequester carbon or reduce agricultural waste and runoff. Similarly, US laws allow developers to drain wetlands only if they pay for the reconstruction of an equivalent area of wetland elsewhere, which has led to the creation of wetland mitigation banks (Ribaudo et al., 2010-this issue). However, in conventional markets, purchasers suffer a direct loss if the product fails, and therefore monitor quality. In contrast, once purchasers of an offset receive certification that the offset has been provided, they share the costs of failure with society as whole. The institution that creates the offset scheme is ultimately responsible for monitoring offset quality, and typically bears the often significant costs of doing so (King and Kuch, 2003).

Finally, for many services such as climate stability, the role of biodiversity in supporting all services, gas regulation, protection from UV radiation, disturbance regulation and so on, non-excludability is a physical characteristic and not a policy variable. Open access use is unavoidable and transaction costs of negotiating market solutions immense. Furthermore, rationing access to the funds that provide the services may be impractical, especially if the services are global and the funds under national control (Farley et al., 2010-this issue), or unjust, especially if those using the fund are less well off than those using the services it provides. There are real costs to providing these services, and non-market PES schemes may be the most just and efficient means to cover them. Payments will require collective institutions representing and capable of collecting revenue from all beneficiaries of the service. Rather than trying to commodify the services and create markets, we must accept that they are public goods, often global, and focus on the challenges of financing them accordingly (Kaul et al., 2002). Ecosystems generally provide a suite of services, many of which are inherently non-excludable, and it may make sense for collective institutions to take the lead, supplemented by more market based approaches where possible. It is no coincidence that so many PES schemes are government sponsored.

Ironically, so called market-like PES solutions such as "green" certification (Ribaudo et al., 2010-this issue) and other private sector payments for biodiversity, scenic beauty, and non-excludable watershed services only work to the extent that individuals fail to behave as conventional economists argue they should. In fact, Koellner (2010-this issue) found that the median for stated motivations for paying for ecosystem services was highest for intrinsic motivations (human welfare and ecological responsibility) and lowest for direct financial benefits. Unfortunately, entirely voluntary payment schemes are likely to be no more effective than voluntary taxes.

\subsection{Rivalry, Scarcity and Rationing}

While excludability determines whether or not access to ecosystem services can be rationed, rivalry and scarcity ${ }^{9}$ determine whether or not it should be. If rival and scarce resources are not rationed, we

\footnotetext{
${ }^{9}$ A resource is scarce when there is not enough to achieve all desired ends, and competition occurs. A resource is rival when consumption by one person diminishes the quantity or quality available for others to use, and non-rival when this is not the case.
}

risk unsustainable overuse, unjust distribution among consumers, and inefficient allocation among products. As Kemkes et al. (2010-this issue) explain, rationing a non-rival or abundant resource is inefficient, as it reduces use and hence value ${ }^{10}$ by creating artificial scarcity. While the implications of non-rivalry are well known and covered in detail by Kemkes et al. (2010-this issue), there are at least three reasons that economists seem to overlook it in designing PES schemes.

First, there is a persistent misconception that rivalry is a dynamic variable, which apparently results from confusing abundance with non-rivalry. Much of the economic literature labels some services as non-rival but congestible, meaning that they are supposedly non-rival at low levels of use but become rival at higher levels. Examples include the physical space required for recreation, such as a golf course or place to lie down on the beach. Such resources are known as club or toll goods. In reality, these services are rival-when my towel occupies a space on a beach, it is not available for your towel to occupy-but fluctuate between abundant and scarce ${ }^{11}$. As the scale of the human economy increases relative to the sustaining and containing ecosystem, more and more formerly abundant services are becoming scarce (Daly and Farley, 2010). Rivalry is an immutable physical characteristic to which PES schemes must adapt, while scarcity is an economic characteristic affected by supply and demand.

Second, the confusion between rival non-rival services extends beyond the scarcity issue. For example, the literature frequently refers to carbon sequestration as non-rival (e.g. Corbera et al., 2009). However, if I use a reforestation project to offset my emissions, it cannot offset yours as well. When designing PES schemes, we should not confuse rival waste absorption capacity for which rationing is desirable with the non-rival climate stability it generates, which cannot be rationed (Farley et al., 2010-this issue; Kemkes et al., 2010this issue). It is helpful to recall the dual nature of natural capital as stocks capable of providing or stockpiling material flows and funds that generate non-ecosystem services at rate over time. While many fund-services are non-rival, all stock-flows are rival. We can ration rival stock-flows to sustain non-rival funds-services. Atmospheric carbon is a rival stock-flow capable of accumulation or decumulation just like stocks of timber and fish, and should be rationed accordingly to provide the service of climate stability.

Third, economists obsessed with market solutions seem to forget about the inefficiencies of artificial scarcity. As a concrete example, the Convention on Biological Diversity together with the World Trade Organization has propertized rights to genetic information from endemic biodiversity. As a result, Indonesia recently considered selling access to a new strain of avian flu to a single corporation to develop a cure, rather than allowing open access for all scientists. Indonesia's reasoning was that a cure discovered by the private sector would be patented and priced too high for Indonesians to afford (McNeil Jr. 2007). Obviously, rationing access to the virus for research reduces the chances of finding a cure, and patenting the vaccine to collect royalties would increase the price, hence pool of unprotected individuals, hence the chance of a global pandemic. We instead require the same type of non-market PES schemes as for inherently open access resources, with payments for conserving genetic diversity unrelated to marginal use of the service, as pointed out by Kemkes et al. (2010-this issue). Commodification of non-rival resources is inefficient and frequently unfair.

\footnotetext{
${ }^{10}$ The word value in economics usually refers to marginal value. Here however we are referring to economic surplus, a measure of total value. Since there is essentially zero marginal cost to using an additional unit of a non-rival service, economic surplus is equivalent to consumer surplus, or the sum of marginal values across all units used.

11 It is only quite recently that we realized congestibility is a question of scarcity or abundance, not rivalry or non-rivalry, which means that even fairly recent publications by Farley and Costanza, including Kemkes et al. (2010-this issue) still refer to non-rival but congestible resources.
} 


\section{Summary, Conclusions and Structure of the Special Section}

In summary, ecosystem services make significant contributions to human welfare, some are essential and have no substitutes, and almost all are becoming increasingly scarce. There are real costs to providing ecosystem services, and we must develop suitable mechanisms for paying for them. Prioritizing efficiency, conventional economists have pursued market based PES schemes that seek to commodify ecosystem services to the extent possible. Recognizing the inherent complexity of ecosystems and prioritizing sustainability and justice over efficiency, ecological economists favor a more adaptive, trandisciplinary approach that does not require commodification. Building on Kemkes et al. (2010-this issue), we argue that the physical and economic characteristics of ecosystem services can inform the institutional form of PES schemes, and also make it explicit where commodification of ecosystem services is impossible or undesirable. For such services, collective institutions based on cooperation, not competition, must either create the conditions required for private sector payments, or accept the public good nature of the services and pay for them directly. Cooperation should be at the same spatial scale over which the service is provided. Table 1 summarizes our results.

However, the fact that market based PES schemes are possible does not mean that they are desirable. While rival and scarce resources must be rationed, price rationing weights preferences by purchasing power, the principle of one dollar, one vote. When a service is essential and non-substitutable and the distribution of purchasing power highly unequal, markets favor the provision of luxuries for the rich over basic needs for the power-croplands and water for flowers instead of food, for example, as happens in Ethiopia (Reynolds et al., 2010-this issue). Democratic mechanisms for allocating essential and non-substitutable resources may be preferable to markets, at least until basic needs are met.

PES systems should prioritize essential, non-substitutable ecosystem services, especially those for which supply is insufficient to satisfy basic needs, or under imminent threat of becoming so. This includes the regulation of climate and atmospheric gases, the provision of water and food, and the biodiversity that sustains all other services. For such immeasurably valuable resources, payment levels should be determined by costs of supply, not some monetary estimate of benefits. However, willingness to pay (WTP) inevitably plays a role, as payments for provision are required, but should be used as a measure of viability, not value. Considering the nature of most services as joint products of intact ecosystems and the irreversible nature of their loss, collective institutions should also take the lead in PES, but we cannot overlook the potential for augmenting collective payments for public services with individual payments for individual services.

Kosoy and Corbera (2010) claim that "re-claiming the public good character of environmental services and discarding any attempt to price and market them as a way to foster conservation" (p. 1235) is radical. We conclude that it is not radical, but rather common sense and necessary.

\subsection{Structure of the Special Section}

As most of the papers in this section resulted from a self-designing atelier process, they were not pre-selected to make a specific argument, though we believe their diversity illustrates a number of our general points.

The special issue begins with two conceptual papers. Kemkes et al. (2010-this issue) review the different types of policy tools for providing ecosystem services and evaluate them according to their coerciveness, visibility, automaticity and directness. They stress the Heredia principles of scale-matching and property rights. In a complementary fashion to this introductory article, they then evaluate the impact that different physical and economic characteristics of different services have on the suitability of PES mechanisms for their provision. Farley et al. (2010-this issue) focus on mechanisms for providing global ecosystem services, with an emphasis on two of the

Table 1

Approaches to PES based on physical and institutional characteristics of the services, with examples from this special issue.

\begin{tabular}{|c|c|c|}
\hline & Excludable (rationing possible) & Non-excludable (rationing not possible) \\
\hline $\begin{array}{l}\text { Rival and scarce } \\
\text { (rationing desirable) }\end{array}$ & $\begin{array}{l}\text { Potential market services } \\
\text { Market based ("Coasian") approaches possible, } \\
\text { but may not be desirable for essential and } \\
\text { non-substitutable services. } \\
\text { Examples: Water quality trading }{ }^{\text {a }} \text {, wetland banking } \\
\text { and offsets }{ }^{\mathrm{b}} \text { (Ribaudo et al.); EU-ETS carbon payments }{ }^{11} \\
\text { if captured by Ethiopia (Reynolds et al.) or Madagascar } \\
\text { (Wendland et al.); industrial water uses } \\
\text { (Daniels et al., 2010-this issue). }\end{array}$ & $\begin{array}{l}\text { Open access regimes } \\
\text { Rationing requires propertization by collective institutions at the scale of the } \\
\text { problem. Under property rules, collective institutions determine supply, } \\
\text { which if sold determines price. Under liability rules, price determines supply. } \\
\text { Examples: Carbon sequestration capacity: Global (Farley et al.), Ethiopia } \\
\text { (Reynolds et al.), Madagascar (Wendland et al.) and USA (Ribaudo et al.). }\end{array}$ \\
\hline Rival and abundant & $\begin{array}{l}\text { Congestible club or toll services } \\
\text { Treat as public good when abundant, or ration access } \\
\text { to cover maintenance and expansion costs. } \\
\text { Treat as potential market good when scarce. } \\
\text { Examples: Fee-hunting (Ribaudo et al.); admission } \\
\text { fees to parks. }\end{array}$ & $\begin{array}{l}\text { Congestible service } \\
\text { Treat as public good when abundant, open access regime when scarce, } \\
\text { if option exists. } \\
\text { Examples: Oxygen (still abundant, inherently non-excludable), collective } \\
\text { institutions must ensure adequate supply; waste absorption capacities for } \\
\text { unregulated pollutants emitted in small quantities. }\end{array}$ \\
\hline $\begin{array}{l}\text { Non-rival } \\
\quad \text { (rationing not desirable) }\end{array}$ & $\begin{array}{l}\text { Inefficient market services } \\
\text { Commodification is inefficient and potentially unjust. } \\
\text { Should be open access and financed by collective } \\
\text { institutions. } \\
\text { Examples: Property rights to biodiversity (Kemkes et al.); } \\
\text { Patents on technologies that protect and restore ecosystem } \\
\text { services (Farley et al.). }\end{array}$ & $\begin{array}{l}\text { Public good services }{ }^{\mathrm{d}} \\
\text { Collective institution finance required and desirable, though the private sector } \\
\text { may voluntarily donate. Open access consumption exists and is desirable. } \\
\text { Examples: Collective institutions: Biodiversity (Farley et al., Wendland et al.) } \\
\text { with scenic beauty and watershed services (Daniels et al., 2010-this issue) } \\
\text { Voluntary private sector: Bicknells thrush habitat } \\
\text { (Kerchner et al., 2010-this issue); organic certification and voluntary carbon } \\
\text { markets (Ribaudo et al.); intrinsically motivated payments for biodiversity, } \\
\text { carbon, scenic beauty and watershed services (Koellner). }\end{array}$ \\
\hline
\end{tabular}

\footnotetext{
a Price is determined by the interaction of market determined demand and collectively determined supply.

b In general, the public sector will remain responsible for monitoring compliance.

Ribaudo argues that fee hunting is a linked good, wherein by paying for hunting access, hunters also support habitat provision for non-target species. However, we suspect that these linked services are not a hunter's primary motivation. Too many hunters on one farm would obviously interfere with each other.

d Non-rival, non-excludable resources are conventionally called public goods. However, all public goods are actually fund-services.
} 
most essential and non-substitutable-climate stability and biodiversity. They suggest a cap and auction scheme for carbon emissions, with revenue dedicated to compensating sovereign nations for maintaining biodiversity habitat, leaving individual nations to decide what specific mechanisms will work best in the national context. They also call for global investments in open source technologies that protect and enhance ecosystem services.

The third paper by Ribaudo et al. describes six different PES schemes in the US related to agriculture, proving useful examples for the matrix above, and assesses approaches for expanding them. Though the article takes a "Coasian" approach, it nonetheless recognizes the critical role of governments in creating and expanding such markets.

The next two papers focus on measuring benefits and costs of service provision to target PES schemes. Wendland et al. (2010-this issue) develop a tool for targeting areas for biodiversity conservation in Madagascar by measuring their potential overlap with carbon sequestration and watershed services and accounting for the opportunity costs of conservation. Kerchner et al. (2010-this issue) develop a separate tool for identifying the lowest cost approach to targeting payments for the conservation of Bicknell's thrush habitat. Though not mentioned in the article, this research arose from previous research on regional payments for watershed services that were found to be inadequate to cover upstream service providers' willingness to accept payments. Combining payment schemes for different services is more likely to cover opportunity costs.

The sixth paper, by Daniels et al. (2010-this issue), also addresses measurement, but in this case the challenges of measuring the success of PES schemes in Costa Rica. The authors conduct a meta-analysis of a number of papers assessing the impacts of PES with differing conclusions. Measurement challenges lie in distinguishing between PES and other policy tools implemented around the same time, deciding what policy tools actual count as PES, filtering out the impacts of structural shifts away from an agricultural economy, and in deciding what constitutes success. They conclude that Costa Rica's scheme has had a limited impact on protecting standing forests, but positive impacts on forest expansion on degraded lands.

The seventh paper by Koellner seeks to empirically assess why firms invest in ecosystem services. Though Koellner begins with conventional economists consumptions concerning firm behavior, he finds that for those firms that indicate a willingness to invest, human welfare and ecological responsibility are on average the dominant motivations, and financial profit the weakest. He further discovers that Costa Rican firms are more willing to invest in public good services, which may be evidence that Costa Rica's PES scheme has an impact on intrinsic motivation.

The final paper by Reynolds et al. takes a practical approach to PES. Participants in an atelier in Ethiopia identified shortages of food, potable water and energy (firewood), all caused by ecological degradation, as major threats to their well-being. Addressing the problem requires investments in natural, human and social capital, but capital investments require surplus production, unavailable in one of the poorest countries on earth. The authors therefore propose payments for carbon sequestration as a revenue source for the necessary capital investments.

\section{Acknowledgements}

We would like to thank the Blue Moon Fund for the funding necessary to carry out the scientific atelier on Payments for Ecosystem Services: From Local to Global, as well as all the participants in the atelier. We would also like to thank the Vermont Agricultural Experiment Station Hatch Program for additional funding.

\section{References}

Ariely, D., Bracha, A., Meier, S., 2009. Doing good or doing well? Image motivation and monetary incentives in behaving prosocially. American Economic Review 99, 544-555.
Barnes, P., 2006. Capitalism 3.0. A Guide to Reclaiming the Commons. Berrett-Koehler Publishers, San Francisco.

Bromley, D.W., 1978. Property rules, liability rules, and environmental economics. Journal of Economic Issues 12.

Bromley, D., 1991. Environment and Economy: Property Rights and Public Policy. Blackwell, Oxford.

Bromley, D.W., 2005. Purging the frontier from our mind: crafting a new fisheries policy. Reviews in Fish Biology and Fisheries 15, 219-227.

Bruijnzeel, L.A., 2004. Hydrological functions of tropical forests: not seeing the soil for the trees? Agriculture, Ecosystems and Environment 104, 185-228.

Burtraw, D., Mansur, E., 1999. The environmental effects of $\mathrm{SO}_{2}$ trading and banking. Environmental Science and Technology 33, 3489-3494.

Coase, R., 1960. The problem of social cost. Journal of Law and Economics 3, 1-44.

Coase, R., 1988. The Firm, the Market and the Law. University of Chicago Press, Chicago.

Corbera, E., Soberanis, C.G.l., Brown, K., 2009. Institutional dimensions of Payments for Ecosystem Services: an analysis of Mexico's carbon forestry programme. Ecological Economics 68, 743-761.

Costanza, R., Daly, H.E., Bartholomew, J.A., 1991. Goals, agenda, and policy recommendations for ecological economics. In: Costanza, R. (Ed.), Ecological Economics: The Science And Management Of Sustainability. Columbia University Press, New York, pp. 1-20.

Daly, H., Farley, J., 2010. Ecological Economics: Principles and Applications: 2nd edition. Island Press, Washington, DC

Daniels, A. Esposito, V., Bagstad, K.J., Moulaert, A., Rodriguez, C.M., 2010-this issue. Understanding the impacts of Costa Rica's PES: Are we asking all the right questions? Ecological Economics.

Ellerman, A.D., Joskow, P.L., 2008. The European Union's Emissions Trading System in Perspective. Pew Center on Global Climate Change, Washington, DC.

Engel, S., Pagiola, S., Wunder, S., 2008. Designing payments for environmental services in theory and practice: an overview of the issues. Ecological Economics 65, 663-674.

Falk, A., Kosfeld, M., 2006. The hidden costs of control. The American Economic Review $96,1611-1630$

Farley, J., 2008. The role of prices in conserving critical natural capital. Conservation Biology 22, 1399-1408.

Farley, J., 2010. Conservation through the economics lens. Environmental Management $45,26-38$.

Farley, J., A. Aquino, A. Daniels, A. Moulaert, D. Lee, and A. Krause. 2010-this issue. Global mechanisms for sustaining and enhancing PES schemes. Ecological Economics.

Fisher, B., Turner, K., Zylstra, M., Brouwer, R., Groot, R.D., Farber, S., Ferrano, P., Green, R., Hadley, D., Harlow, J., Jefferiss, P., Kirby, C., Morling, P., Mowatt, S., Naidoo, R. Paavola, J., Strassburg, B., Yu, D., Balmford, A., 2008. Ecosystem Services and Economic Theory: Integration for Policy-Relevant Research. Ecological Applications $18,2050-2067$.

Frey, B.S., Jegen, R., 2001. Motivation crowding theory. Journal of Economic Surveys 15, 589-611.

Georgescu-Roegen, N., 1971. The Entropy Law and the Economic Process. Harvard University Press, Cambridge, MA.

Gneezy, U., Rustichini, A., 2000. Pay enough or don't pay at all. The Quarterly Journal of Economics 115, 791-810.

Kaul, I., Goulven, K.L., Schnupf, M. (Eds.), 2002. Financing Global Public Goods: New Tools for New Challenges: A Policy Dialogue. United Nations Development Program, New York.

Kemkes, R. J. 2008. Policy Tool Choice for Ecosystem Service Provision: Payments and Public Information. Masters Thesis. Community Development and Applied Economics. University of Vermont, Burlington.

Kemkes, R. J., J. Farley, and C. J. Koliba. 2010. Determining when payments are an effective policy approach to ecosystem service provision. Ecological Economics (this issue).

Kerchner, C. M. Honzak, R. Kemkes, A. Richardson, J. Townsend, and C. C. Rimmer. 2010. Designing spatially explicit incentive programs for habitat conservation: A case study of the Bicknell's thrush wintering grounds. Ecological Economics (this issue).

King, D.M., Kuch, P.J., 2003. Will nutrient credit trading ever work? An assessment of supply and demand problems and institutional obstacles. Environmental Law Reporter 10352-10368.

Koellner, T. 2010-this issue. Why and how much are firms willing to invest in ecosystem services from tropical forests? A comparison of international and Costa Rican firms. Ecological Economics.

Kosoy, N., Corbera, E., 2010. Payments for ecosystem services as commodity fetishism. Ecological Economics 69, 1228-1236.

Kosoy, N., Martinez-Tuna, M., Muradian, R., Martinez-Alier, J., 2007. Payments for environmental services in watersheds: insights from a comparative study of three cases in Central America. Ecological Economics 61, 446-455.

Landell-Mills, N., Porras, I.T., 2002. Silver Bullet or Fools' Gold? A Global Review of Markets for Forest Environmental Services and their Impact on the Poor. International Institute for Environment and Development, London.

Lohman, L. (Ed.), 2006. Carbon Trading: A Critical Conversation on Climate Change, Privatisation and Power. Dag Hammarskjold Foundation, Durban Group for Climate Justice and the Corner House, Uppsala, Sweden.

Loureiro, W. 2002. Contribuição do ICMS Ecológico a Conservação da Biodiversidade no Estado do Paraná. Tese de Doutorado. Engenharia Florestal. Universidade Federal do Parana, Curitiba.

Malghan, D., 2006. On Being the Right Size: A Framework for the Analytical Study of Scale, Economy, and Ecosystem. Public Affairs. University of Maryland, College Park.

May, P., Veiga Neto, F., Denardin, V., Loureiro, W., 2002. Using fiscal instruments to encourage conservation: municipal responses to the ecological value added tax in Parana and Minas Gerais, Brazil. In: Pagiola, S., Bishop, J., Landell-Mills, N. (Eds.), Selling Forest Environemtal Services: Market-Based Mechanisms for Conservation and Development. Earthscan Publications, Sterling, Virginia, pp. 173-199. 
McCauley, D.J., 2006. Selling out on nature. Nature 443, 27-28.

McNeil, Jr., D. 2007. Indonesia May Sell, Not Give, Bird Flu Virus to Scientists. New York Times, New York, February 7, 2007.

Muradian, R., Corbera, E., Pascual, U., Kosoy, N., May, P.H., 2010. Reconciling theory and practice: an alternative conceptual framework for understanding payments for environmental services. Ecological Economics 69, 1202-1208.

Norgaard, R.B., 2010. Ecosystem services: from eye-opening metaphor to complexity blinder. Ecological Economics 69, 1219-1227.

Pagiola, S., Arcenas, A., Platais, G., 2005. Can payments for environmental services help reduce poverty? An exploration of the issues and the evidence to date from Latin America. World Development 33, 237-253.

Pagiola, S., Ramírez, E., Gobbi, J., de Haan, C., Ibrahim, M., Murgueitio, E., Ruíz, J.P., 2007. Paying for the environmental services of silvopastoral practices in Nicaragua. Ecological Economics 64, 374-385.

Porras, I., Grieg-Gran, M., Neves, N., 2008. All That glitters: A Review of Payments for Watershed Services in Developing Countries. The International Institute for Environment and Development, London.

Reynolds, T. W., J. Farley, and C. Huber. 2010-this issue. Investing in human and natural capital: An alternative paradigm for sustainable development in Awassa, Ethiopia. Ecological Economics.

Ribaudo, M., C. Greene, LeRoy Hansen, and D. Hellerstein. 2010-this issue. Ecosystem Services from Agriculture: Steps for Expanding Markets. Ecological Economics.

Ring, I., 2008. Integrating local ecological services into intergovernmental fiscal transfers: the case of the ecological ICMS in Brazil. Land Use Policy 25, 485-497.
Robertson, M.M., 2006. The nature that capital can see: science, state, and market in the commodification of ecosystem services. Environment and Planning D-Society \& Space 24, 367-387.

Rørstad, P.K., Vatn, A., Kvakkestad, V., 2007. Why do transaction costs of agricultural policies vary? Agricultural Economics 36, 1-11.

United Nations, 1982. United Nations Convention on the Law of the Sea. available online at http://www.un.org/Depts/los/convention_agreements/convention_overview_convention.htm.

Vatn, A., 2010. An institutional analysis of payments for environmental services. Ecological Economics 69, 1245-1252.

Vatn, A., Bromley, D.W., 1994. Choices without prices without apologies. Journal of Environmental Economics and Management 26, 129-148.

Wendland, K. J., M. Honzak, R. Portela, B. Vitale, S. Rubinoff, and J. Randrianarisoa. 2010 this issue. Targeting and implementing payments for ecosystem services: Opportunities for bundling biodiversity conservation with carbon and water services in Madagascar. Ecological Economics.

Wunder, S., 2005. Payments for Environmental Services: Some Nuts and Bolts. Occasional Paper No. 42. Center for International Forestry Research, Nairobi, Kenya.

Wunder, S., 2008. Payments for environmental services and the poor: concepts and preliminary evidence. Environment and Development Economics 13, 279-297.

Wunder, S., Engel, S., Pagiola, S., 2008. Taking stock: a comparative analysis of payments for environmental services programs in developed and developing countries. Ecological Economics 65, 834-852. 